\title{
AZAN DAN KAIFIATNYA DI TENGAH WABAH COVID-19
}

\author{
Muhammad Yusram \\ Sekolah Tinggi Ilmu Islam dan Bahasa Arab (STIBA) Makassar \\ Email: yusrananshar@stiba.ac.id
}

\begin{abstract}
Keywords:
ABSTRACT

Azan, Shari'a, Pandemic, Azan is an important matter in performing obligatory prayers; it Covid-19, Muezzin. is an announcement of the beginning of five-time daily prayers. However, problems arise when covid-19 pandemic occurs in the midst of society and a particular way (kaifiyat) of azan recommended in the Shari'a is required. The aim of this research was to describe the law and the characteristics of azan during the covid-19 pandemic. Therefore, descriptive qualitative research methods were used in this study so were content analysis techniques and library research approaches in the analysis process. The results of the study show that the law of azan in the midst of the covid-19 pandemic is fardu kifayah (collectively obligatory), while the additional enunciations of azan that was prescribed in the excused condition of the congregational prayer include: Shallū fî̀ rihālikum, Shallū fì buyūtikum, Alā Shallū fir rihàl, and Ash Shalāh fir Rihàl. The pronouncement of the additional enunciations of azan is after the usual as usual, and this is based on the clearest passage according to the narration of Ibn Umar radhiyallahu anhuma. However, the scholars also allow the muezzin to pronounce those enouncements in place of "Hayya "ala ash shalā $h$ " when azan is called out.
\end{abstract}

Kata kunci:
Azan, Syariat, pandemi,
covid-19, Muazin.
ABSTRAK

Azan merupakan perkara penting dalam pelaksanaan salat fardu,
ia merupakan pertanda masuknya salat lima waktu. Namun,
persoalan timbul tatkala terjadi pandemi covid-19 di tengah-
tengah masyarakat dan membutuhkan cara yang khusus (kaifiat)
azan yang dianjurkan dalam syariat. Penelitian ini bertujuan
untuk mendeskripsikan hukum dan kaifiat azan di masa pandemi
covid-19. Dengan demikian, metode penelitian kualitatif
deskriptif digunakan dalam kajian ini sembari menerapkan
teknik analisis isi (content analysis) dan pendekatan riset
kepustakaan (library research) dalam proses pengkajiannya. Hasil
penelitian ditemukan bahwa hukum azan di tengah pandemi
covid-19 adalah fardu kifayah, sementara penambahan lafaz azan
yang disyariatkan dalam kondisi uzur berjemaah di antaranya:
Shallü fí rihālikum; Shallū fī buyütikum; Alä Shallü fir rihāl; dan
Ash Shalāh fir Rihāl. Adapun pengucapan lafaz penambahan
azan tersebut diucapkan setelah mengumandankan azan secara
normal sebagaimana biasanya, dan hal ini didasari atas nas yang




\section{PENDAHULUAN}

Azan adalah panggilan untuk melaksanakan salat fardu. Di samping itu, ia juga sebagai pertanda bahwa waktu salat telah masuk dan akan segera ditegakkan. Azan merupakan salah satu syiar Islam yang termulia dan senantiasa dikumandangkan di negeri-negeri kaum muslimin. Setiap hari, sebanyak lima kali kaum muslimin mendengar seruan azan yang berkumandang di masjidmasjid. Azan ini memberitahukan telah masuknya waktu salat agar kaum muslimin yang tengah sibuk dengan berbagai aktivitasnya sejenak berhenti dan beristirahat $^{1}$ lalu bergegas memenuhi seruan Allah Ta'ala dan beribadah kepada-Nya. Demikian pula yang tengah pulas tertidur segera terjaga lantas berwudu dan mengenakan pakaian terbaiknya untuk menunaikan salat berjemaah.

Allah Ta'ala telah memuji para hamba-Nya terutama kaum lelaki yang bersegera menjawab panggilan azan ketika dikumandangkan untuk melaksanakan salat berjemaah. Allah Ta'ala berfirman:

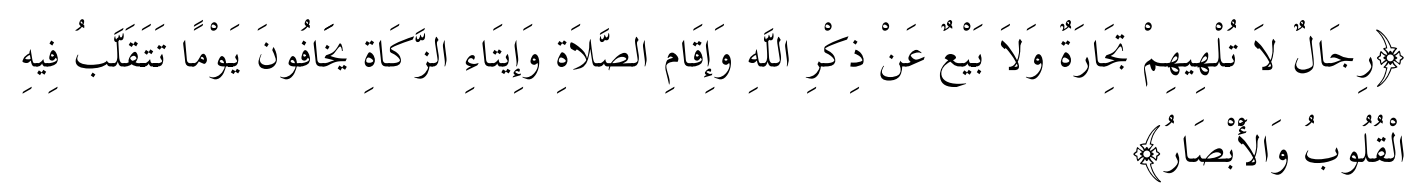

Terjemahnya:

"Laki-laki yang tidak dilalaikan oleh perniagaan dan tidak (pula) oleh jual beli dari mengingat Allah, dan (dari) mendirikan salat, dan (dari) menunaikan zakat. Mereka takut kepada suatu hari yang (di hari itu) hati dan penglihatan menjadi goncang." (Q.S. al-Nur/24: 37)

${ }^{1}$ Rasulullah shallallahu 'alaihi wasallam bersabda kepada muazin terbaik sepanjang zaman,

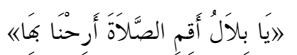

"Wahai Bilal, dirikanlah salat (azan). Dan buatlah kami istirahat dengan ibadah salat." (H.R. Abu Dawud no. 4985 dan Ahmad no. 23088 serta disahihkan oleh al-Albani di Shahih al-Jami' al- Shaghir, Jilid II (Beirut: Al Maktab Al Islami), h. 1307 dan takhrij Misykah al-Mashabih, Jilid I (Cet. III; Beirut: Al Maktab Al Islami, 1985 M), h. 393. 
Abdullah bin Umar radhiyallahu 'anhuma mengatakan bahwa ayat itu turun sebagai pujian kepada mereka yang berada di pasar. Lalu ketika azan dikumandangkan mereka bergegas menutup toko dan kedai mereka kemudian menuju ke masjid. ${ }^{2}$ Namun, ketika virus covid-19 telah menjadi pandemi maka para ulama di berbagai negara ${ }^{3}$ termasuk pihak MUI $^{4}$ di negara kita telah mengeluarkan fatwa terkait pelaksanaan salat berjemaah di masjid. Fatwa-fatwa yang dikeluarkan dengan merujuk pada dalil-dalil syariat dan tinjauan maqashid syariah ini menyebutkan bahwa untuk sementara salat berjemaah tidak dilaksanakan di masjid-masjid. Pelarangan ini terutama ditujukan untuk daerahdaerah yang tidak terkendali dan potensi penularannya tinggi. Fatwa tersebut dimaksudkan untuk menghindari dan meminimalisir tersebarnya virus yang sangat berbahaya dan mematikan ini.

Pertanyaan yang mungkin timbul, pada saat salat tidak dianjurkan secara berjemaah di masjid-masjid, apakah azan tetap disyariatkan untuk dikumandangkan? Lalu jika tetap disyariatkan, apakah lafaznya tetap sebagaimana ketika dikumandangkan dalam kondisi normal?. Dengan demikian, tulisan ini mencoba menjawab dua pertanyaan utama tersebut dengan beberapa rincian hukum-hukum lain yang perlu diketahui serta beberapa pendahuluan penting terkait dengan azan.

Penelitian ini menggunakan metode pendekatan kualitatif deskriptif. Metode tersebut merupakan upaya memahami berbagai konsep yang ditemukan dalam proses penelitian, dengan menggunakan teknik content analysis (analisis isi) dan riset kepustakaan (library research). Teknik content analysis merupakan metode penelitian yang digunakan untuk mengetahui simpulan dari sebuah teks. Dengan kata lain, analisis isi merupakan metode penelitian yang ingin mengungkap gagasan penulis yang termanifestasi maupun yang laten. Sedangkan riset kepustakaan (library research) pada penelitian ini menggunakan jenis dan sumber data sekunder yang diperoleh dari hasil penelitian, artikel dan buku-buku referensi yang membahas topik yang berkaitan dengan masalah penelitian. ${ }^{5}$

\footnotetext{
${ }^{2}$ Lihat: Husain bin Mas'ud Al Baghawi, Ma’alim At Tanzil/ Tafsir Al Baghawi, Jilid VI (Cet. IV; Riyadh: Daar Thayyibah, 1417 H). h. 51

${ }^{3}$ Lihat: Mas'ud Shabri, Fatawa al-Ulama Haula Fairus Kuruna, (Cet. I; Kairo: Daar Al Basyir, $1441 \mathrm{H})$, h. 12-44.

${ }^{4}$ Lihat: https://mui.or.id/berita/27674/fatwa-penyelenggaraan-ibadah-dalam-situasi-terjadi-wabahcovid-19/ Diakses pada tanggal 22 April 2020.

${ }^{5}$ Azwar Iskandar dan Khaerul Aqbar, Kedudukan Ilmu Ekonomi Islam di Antara Ilmu Ekonomi dan Fikih Muamalah: Analisis Problematika Epistemologis, Nukhbatul 'Ulum: Jurnal Bidang Kajian Islam, Vol. 5, No. 2 (2019), h. 88-105. https://journal.stiba.ac.id/index.php/nukhbah/article/view/77.
} 


\section{PEMBAHASAN}

\section{Definisi Azan}

Azan secara bahasa bermakna al-i'laam atau al-i'laan yang secara umum berarti pengumuman atau pemberitahuan ${ }^{6}$, sebagaimana firman Allah Ta'ala:

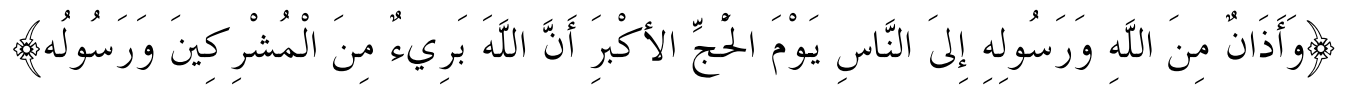

Terjemahnya:

"Dan pengumuman dari Allah dan Rasul-Nya kepada umat manusia di hari haji akbar bahwa Allah dan Rasul-Nya berlepas diri dari kaum musyrikin..." (Q.S. al-Taubah/9: 3).

Adapun secara syariat, Imam Ibnu Qudamah mendefinisikannya sebagai berikut:

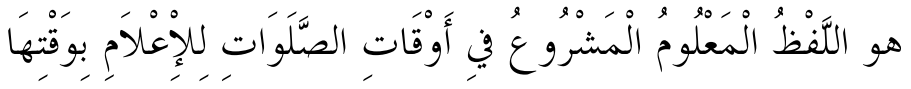

Artinya:

"Azan adalah lafaz yang telah diketahui berdasarkan dalil-dalil syariat dan (dikumandangkan) pada saat salat-salat fardu sebagai informasi waktunya (telah masuk)."7

Ibnul Mulaqqin rahimahullah berkata:

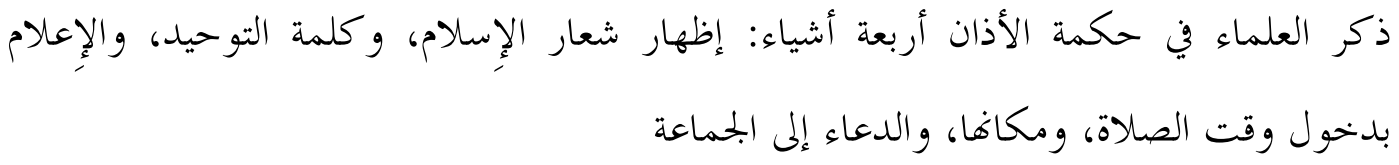

Artinya:

"Para ulama menyebutkan empat hikmah azan: (1) menampakkan syiar Islam, (2) menegakkan kalimat tauhid, (3) informasi masuknya waktu salat, (4) seruan untuk melakukan salat berjemaah."

\section{Fadilah Azan ${ }^{9}$}

Salah satu tanda sempurnanya syariat Islam ini adalah memberi motivasi kepada umatnya untuk melaksanakan ibadah dengan menyebutkan keutamaan ibadah tersebut. Begitu pula azan, banyak dalil yang menjelaskan

${ }^{6}$ Lihat: Ali bin Muhammad al-Jurjani, At-Ta'rifaat, (Cet. I; Beirut: Daar Al Kutub Al Ilmiyah, 1403 H), h. 16.

${ }^{7}$ Abdullah bin Ahmad bin Muhammad bin Qudamah Al Maqdisi, Al-Mughni, Jilid I (Kairo: Maktabah Al Qahirah, 1388 H), h. 292.

${ }^{8}$ Umar bin Ali bin Ahmad bin Mulaqqin, Al-I'lam bi Fawaid 'Umdah al-Ahkam, Jilid II (Cet. I; Riyadh; Daar Al 'Ashimah, 1417 H), h. 420.

${ }^{9}$ Abdul Aziz bin Marzuq al-Tharifi, Al-Masaail al-Muhimmah fi al-Adzan wa al-Iqamah, (Cet. III; Riyadh: Maktabah Daar Al Minhaj) h. 10-11. 
tentang keutamaannya dan sekaligus orang yang menyerukannya (muazin), di antaranya:

1) Perkataan yang terbaik

Allah Ta'ala berfirman:

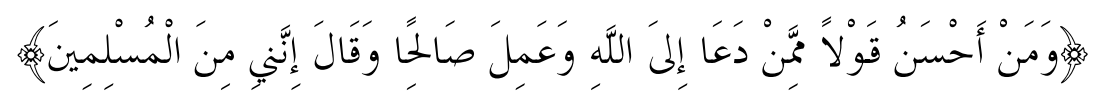

Terjemahnya:

"Siapakah yang lebih baik perkataannya daripada orang yang menyeru kepada Allah, mengerjakan amal yang saleh, dan berkata: "Sesungguhnya aku termasuk orang-orang yang berserah diri?" (Q.S. Fushshilat/41: 33).

Aisyah radhiyallahu 'anha mengatakan, "Orang (yang dimaksud dalam ayat ini) adalah muazin, ketika dia mengumandangkan, "Hayya 'ala ash-shalah" maka dia telah menyeru kepada Allah". ${ }^{10}$

2) Azan adalah amal saleh yang sepatutnya manusia berlomba-lomba melakukannya.

Abu Hurairah radhiyallahu 'anhu menceritakan bahwa Rasulullah shallallahu 'alaihi wasallam bersabda:

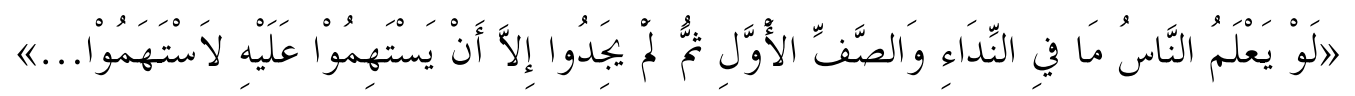

Artinya:

"Seandainya orang-orang mengetahui besarnya pahala yang didapatkan dalam azan dan saf pertama kemudian mereka tidak dapat memperolehnya kecuali dengan undian niscaya mereka rela berundi untuk mendapatkannya."11

3) Setan lari ketika mendengar azan.

Dari Abu Hurairah radhiyallahu 'anhu juga, ia mengabarkan bahwa Rasulullah shallallahu 'alaihi wa sallam bersabda:

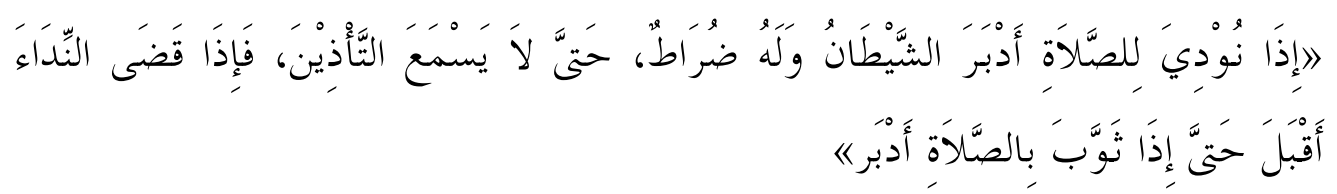

Artinya:

${ }^{10}$ Ibnu Katsir mengatakan bahwa tafsiran seperti ini juga diriwayatkan dari Ibnu Umar radhiyallahu 'anhuma dan Ikrimah. Lihat: Ismail bin Umar bin Katsir Al Dimasyqi, Tafsir Al Quran Al Azhim, Jilid VII (Cet. II; Riyadh, Daar Thayyibah, 1420 H) h. 180.

${ }^{11}$ H.R. Bukhari no. 615 dan Muslim no. 980. 
"Apabila diserukan azan untuk salat, setan pergi berlalu dalam keadaan kentut yang terdengar hingga ia tidak mendengar azan. Bila muazin selesai mengumandangkan azan, ia datang hingga ketika diserukan ikamah ia berlalu lagi..."12

4) Para muazin di hari kiamat memiliki leher terpanjang.

Dari Muawiyah radhiyallahu 'anhu berkata: Aku pernah mendengar Rasulullah shallallahu 'alaihi wasallam bersabda:

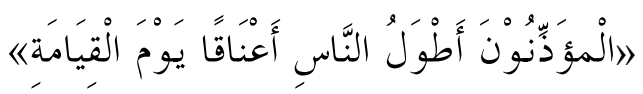

Artinya:

"Para muazin adalah orang yang paling panjang lehernya pada hari kiamat."13

Imam Nawawi telah menjelaskan beberapa penafsiran ulama tentang hadis ini, di antaranya: para muazin adalah orang yang paling besar pengharapannya terhadap rahmat dan pahala Allah di hari kiamat, para muazin memiliki leher terpanjang di hari kiamat dalam makna hakiki agar mereka tidak ditimpa kesusahan dan peluh, mereka menjadi pemimpin dan pemuka di hari kiamat, mereka adalah manusia yang paling banyak pengikutnya, paling banyak amal salehnya dan paling awal masuk surga. ${ }^{14}$

5) Seluruh makhluk yang mendengarkan azan akan menjadi saksi kebaikan bagi muazin di hari kiamat kelak

Dari Abu Said al-Khudri radhiyallahu 'anhu mengabarkan dari Rasulullah shallallahu 'alaihi wa sallam bahwa ia bersabda:

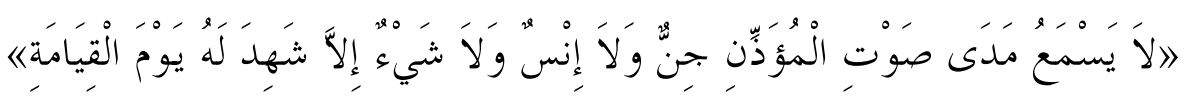

Artinya:

"Tidaklah jin dan manusia serta tidak ada sesuatu pun yang mendengar suara lantunan azan dari seorang muazin melainkan akan menjadi saksi kebaikan bagi si muazin pada hari kiamat."15

6) Rasulullah shallallahu 'alaihi wa sallam mendoakan para imam dan muazin.

Dari Aisyah radhiallahu 'anha ia berkata, "Aku pernah mendengar Rasulullah shallallahu 'alaihi wa sallam bersabda,

${ }^{12}$ H.R. Bukhari no. 608 dan Muslim no. 1267.

${ }^{13}$ H.R. Muslim no. 850.

14 Yahya bin Syaraf An Nawawi, Al-Minhaj Syarhu Shahih Muslim bin Hajjaj, Jilid IV (Cet. II; Beirut: Daar Ihya At Turots Al Arabi, 1392 H), 92.

${ }^{15}$ H.R. Bukhari no. 609. 


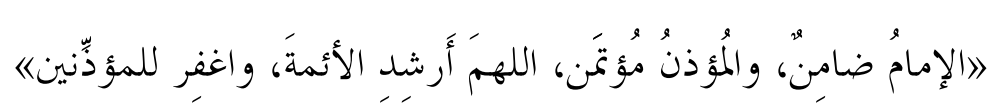

Artinya:

"Imam adalah penjamin sedangkan muazin adalah orang yang diamanahi. Ya Allah berikan petunjuk lurus kepada para imam dan ampunilah para muazin." 16

\section{Hukum dan Kedudukan Azan}

Terdapat beberapa dalil dalam al-Qur'an dan hadis yang menjelaskan tentang disyariatkannya azan, di antaranya: Allah Ta'ala berfirman:

$$
\text { هَ }
$$

Terjemahnya:

"Dan apabila kamu menyeru (mereka) untuk (mengerjakan) salat, mereka menjadikannya buah ejekan dan permainan. Yang demikian itu adalah karena mereka benar-benar kaum yang tidak mau mempergunakan akal." (Q.S. al-Maidah/5: 58).

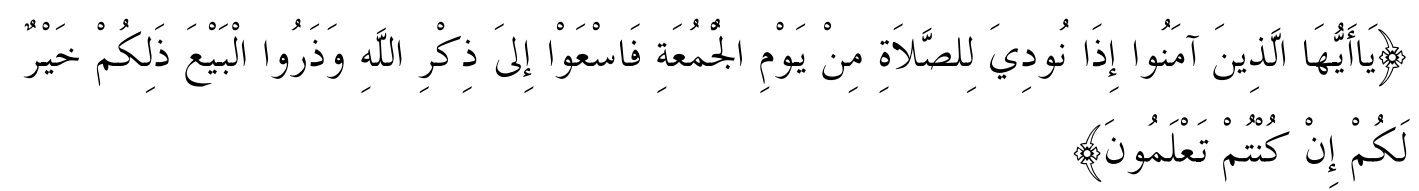

Terjemahnya:

"Hai orang-orang beriman, apabila diseru untuk menunaikan salat Jumat, maka bersegeralah kamu mengingat Allah dan tinggalkanlah jual beli. Yang demikian itu lebih baik bagimu jika kamu mengetahui." (Q.S. alJumuah: 9).

Anas bin Malik radhiyallahu 'anhu berkata:

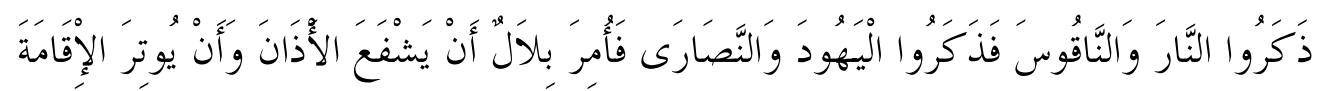

Artinya:

"Para sahabat menyebut-nyebut tentang api dan lonceng (dalam mengusulkan cara memanggil salat). Lalu ada juga di antara mereka yang mengusulkan seperti kebiasaan orang-orang Yahudi dan Nasrani. Maka

${ }^{16}$ H.R. Abu Dawud no. 517 dan Tirmidzi no. 207 serta disahihkan oleh al-Albani, Shahih al-Jami' al-Shaghir, Jilid I (Beirut: Al Maktab Al Islami), h. 539. 
Bilal diperintahkan untuk mengumandangkan azan dengan bilangan genap dan ikamah dengan bilangan ganjil."17

Abdullah bin Umar radhiyallahu 'anhuma menceritakan:

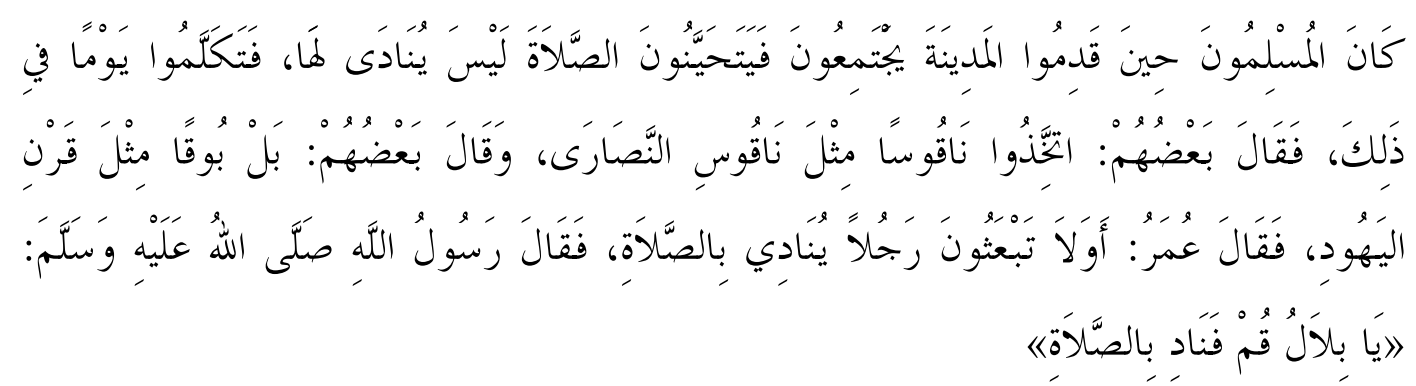

Artinya:

"Dahulu kaum muslimin ketika tiba di Madinah, mereka berkumpul, lalu menanti waktu salat lima waktu, dan tidak ada seorang pun yang memanggil azan untuk salat. Lalu mereka membicarakan hal tersebut di suatu hari. Sebagian mereka berkata, 'Jadikanlah lonceng (sebagai alat pemanggil) sebagaimana lonceng orang-orang Nasrani.' Dan sebagian mereka berkata, 'Jadikanlah terompet (sebagai alat pemanggil) seperti terompet orang-orang Yahudi.' Lalu Umar radhiyallahu anhu berkata, 'Mengapa kalian tidak mengutus seorang laki-laki yang menyerukan salat.' Rasulullah shallallahu 'alaihi wasallam lalu bersabda, "Berdirilah wahai Bilal, lalu serukanlah salat."18

Beberapa ulama di antaranya Ibnu Abdil Barr ${ }^{19}$, Ibnu Hubairah ${ }^{20}$, Nawawi $^{21}$, Ibnu Qudamah ${ }^{22}$ dan Badruddin a-'Aini' ${ }^{23}$ telah menukil ijmak tentang disyariatkannya azan. Setelah para ulama bersepakat tentang disyariatkannya azan lalu mereka beda pandangan dalam hal hukumnya, apakah azan itu wajib ataukah sunah muakadah?. ${ }^{24}$ Imam Malik berpendapat bahwa

${ }^{17}$ H.R. Bukhari no. 603 dan Muslim no. 378.

${ }^{18}$ H.R. Bukhari no. 604 dan Muslim no. 377.

${ }^{19}$ Yusuf bin Abdullah bin Muhammad bin Abdil Barr, Al-Istidzkar, Jilid IV (Cet. I; Beirut: Daar Al Kutub Al Ilmiyyah, 1421 H), h. 11.

${ }^{20}$ Yahya bin bin Muhammad bin Hubairah, Al-Ifshah 'an Ma'aani Ash Shihah. Jilid I (Riyadh: Daar Al Wathan, 1417 H). h. 64.

${ }^{21}$ Abdullah bin Ahmad bin Muhammad bin Qudamah Al Maqdisi, Al-Mughni, Jilid II (Kairo: Maktabah Al Qahirah, 1388 H), h. 56.

Al Fikr), h. 83.

${ }^{22}$ Yahya bin Syaraf An Nawawi, Al-Majmu' Syarhu Al Muhadzdzab, Jilid III (Beirut: Daar

${ }^{23}$ Mahmud bin Ahmad bin Musa Al ‘Aini Al Hanafi, Al-Binayah Syarhu al-Hidayah, Jilid II (Cet. I; Beirut, Daar Al Kutub Al 'Ilmiyyah, 1420 H), h. 85.

${ }^{24}$ Lihat: Muhammad bin Ahmad bin Muhammad Ibn Rusyd, Bidayah al-Mujtahid wa Nihyah al-Muqtashid, Jilid I (Kairo: Daar Al-Hadits, 1425 H), h. 114 dan juga al-Amin al-Hajj Muhammad 
azan wajib dikumandangkan di masjid-masjid yang dilaksanakan salat jemaah, demikian pula Imam Ahmad berpendapat hukumnya fardu kifayah. Adapun Imam Abu Hanifah dan Imam Syafii keduanya mengatakan sunah bagi yang salat sendirian dan sunah muakadah ketika salat jemaah.

Dari perbedaan pendapat tersebut tampaknya yang kuat adalah pendapat yang menyatakan hukum azan adalah fardu kifayah. Dengannya tidak boleh di suatu negeri tidak dikumandangkan azan sama sekali. Di antara dalil yang menunjukkan hukum azan fardu kifayah:

1) Azan merupakan salah satu syiar Islam yang besar, di mana syiar ini tidak pernah ditinggalkan oleh Rasulullah shallallahu 'alaihi wasallam dan para khalifah sesudahnya walaupun hanya sekali.

2) Berkumandangnya azan dijadikan tolok ukur oleh Rasulullah shallallahu 'alaihi wasallam apakah suatu negeri termasuk negeri Islam ataukah tidak. Sahabat yang mulia Anas bin Malik radhiyallahu 'anhu menceritakan bahwa,

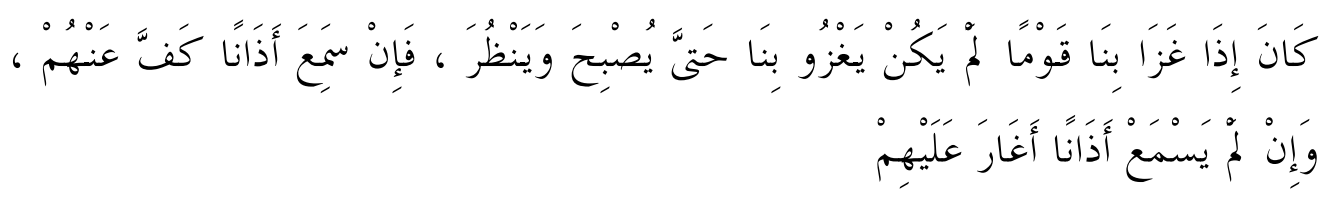

Artinya:

"Nabi shallallahu 'alaihi wasallam dahulu jika akan menyerang satu kaum, beliau tidak memerintahkan kami menyerang pada malam hari hingga menunggu waktu Subuh. Apabila azan Subuh terdengar, maka beliau tidak jadi menyerang. Namun bila tidak mendengarnya, maka beliau menyerang mereka." 25

3) Nabi shallallahu 'alaihi wasallam telah memerintahkan untuk dikumandangkan azan dan mengangkat salah seorang jadi imam pada saat salat berjemaah. Beliau bersabda,

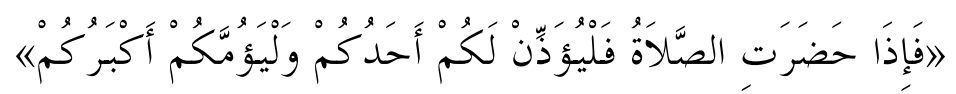

Artinya:

Ahmad, Dalil al-Aimmah wa al-Muadzdzinin, (Cet. I, Khartoum: Syarikah Mathabi' As Sudan, 1426 H), h. 6.

${ }^{25}$ H.R. Bukhari no. 610 dan Muslim no. 382. 
"Jika waktu salat telah tiba, salah seorang di antara kalian hendaknya mengumandangkan azan untuk kalian dan yang paling tua di antara kalian menjadi imam." 26

Syekhul Islam Ibnu Taimiyah rahimahullah ketika ditanya hukum azan beliau menerangkan:

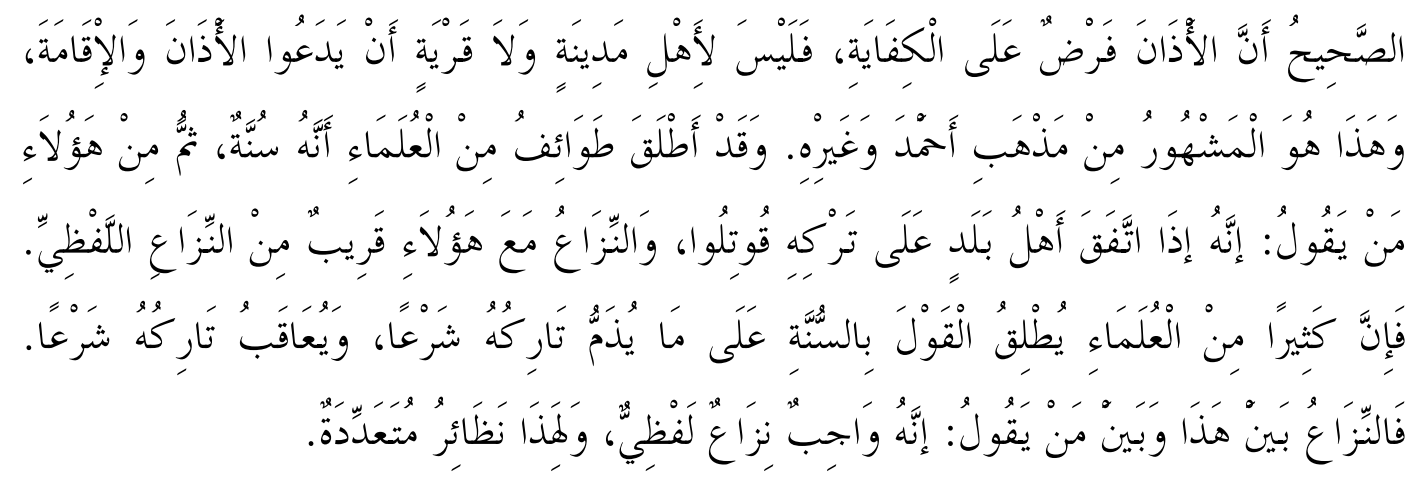

Artinya:

"Yang tepat, hukum azan adalah fardu kifayah. Tidak boleh jika ada di suatu negeri atau kampung yang tidak ada azan sama sekali. Demikian pendapat yang masyhur dalam mazhab Imam Ahmad dan lainnya. Sebagian ulama ada yang menyatakan bahwa hukum azan adalah sunah. Namun, mereka selanjutnya mengatakan bahwa jika di suatu negeri meninggalkan azan, maka boleh diperangi. Maka sebenarnya yang terjadi adalah perselisihan lafaz (dalam mengungkapkan hukum). Karena banyak di antara ulama yang memaksudkan hukumnya sunah dengan makna jika ditinggalkan tercela menurut syariat. Jadi hakikatnya ikhtilaf yang terjadi adalah perbedaan lafaz saja dengan yang berpendapat wajib." 27

\section{Hukum Azan di Tengah Wabah Covid-19}

Hukum-hukum azan yang telah diterangkan di atas adalah pada saat kondisi normal di mana kaum muslimin khususnya yang laki-laki diserukan untuk menghadiri salat secara berjemaah di masjid-masjid kaum muslimin. Bagaimana hukum azan dengan kondisi saat sekarang ini di saat ada anjuran untuk tidak berkumpul dalam jumlah yang banyak termasuk di tempat-tempat ibadah (masjid) bahkan sebagiannya ditutup? Apakah azan tersebut tetap dikumandangkan di masjid atau tidak?

${ }^{26}$ H.R. Bukhari no. 602 dan Muslim no. 674.

${ }^{27}$ Ahmad bin Abdul Halim bin Abdussalam Ibn Taimiyah. Al-Fatawa al-Kubra, Jilid II (Cet. I, Beirut: Daar Al Kutub Al Ilmiyyah, 1408 H), h. 41. 
Berdasarkan penjelasan hukum azan dan kedudukannya di atas maka para ulama kita menganjurkan agar masjid-masjid tetap mengumandangkan azan. Paling tidak di satu lingkungan tertentu walaupun salat jemaah tidak ditegakkan. Di antara dalil dan hujah pendapat ini:

Pertama, hukum azan adalah fardu kifayah, dengan demikian jika sebagian masjid di satu lingkungan tertentu telah melaksanakannya maka yang lain tidak berdosa, namun jika seluruh kaum muslimin tidak melakukannya maka seluruhnya berdosa. Para ulama yang tergabung di Komisi Tetap Riset dan Fatwa Kerajaan Arab Saudi ketika ditanya apakah wajib mengumandangkan azan di setiap masjid yang berada di satu lingkungan dengan menggunakan pengeras suara walaupun suara azan salah satu masjid kadang sudah terdengar di seluruh lingkungan tersebut? Mereka menjawab:

$$
\text { الأذأنوان فرض كفاية، فإذا أذن مؤذن في الحي وأسعع سكانه أجزأهم، ويشرع لأهل كل مسجد أن }
$$

Artinya:

"Azan hukumnya fardu kifayah, maka jika salah seorang muazin di lingkungan tersebut telah azan yang memperdengarkan seluruh penduduk lingkungan tersebut maka sudah cukup. Namun demikian pada dasarnya setiap masjid tetap disyariatkan untuk azan berdasarkan dalil-dalil yang sifatnya umum."28

Kedua, di antara hikmah dan tujuan terbesar dari azan adalah untuk menebarkan dan menegakkan syiar Islam serta permakluman bahwa negeri tersebut didiami oleh kaum muslimin.

Ketiga, azan bukan sekadar untuk mengajak kaum muslimin melaksanakan salat berjemaah di masjid, namun salah satu fungsi penting dari azan adalah untuk menginformasikan dan mengingatkan umat Islam dengan berbagai aktivitasnya bahwa waktu salat telah masuk.

Keempat, para ulama mengiaskan kondisi sekarang ini dengan kondisi pada saat hujan lebat dan keadaan serta cuaca yang tidak memungkinkan untuk ke masjid. Dalam kondisi seperti itu, Nabi Muhammad shallallahu 'alaihi

${ }^{28}$ Ahmad bin Abdurrazzaq Al Duways, Fatawa al-Lajnah al-Daimah, Jilid VI (Riyadh: Riasah Al Idarah Al Buhuts Al Ilmiyyah wa Al-Ifta), h. 75. 
wasallam tetap memerintahkan untuk mengumandangkan azan namun dengan sedikit perubahan pada lafaznya. ${ }^{29}$

\section{Dalil Disyariatkannya Azan dalam Kondisi Adanya Uzur untuk Tidak Hadir ke Masjid}

Para ulama telah sepakat bahwa boleh bagi muazin mengucapkan: "ashshalātu fir rihāl" atau "shallù fì rihālikum" atau "shallū fì buyütikum" jika ada uzur berupa hujan deras atau becek, lumpur atau cuaca yang sangat dingin demikian pula angin yang sangat kencang berdasarkan beberapa hadis sahih yang menjelaskan masalah tersebut. Ihwal tersebut, tabiin yang mulia Nafi' berkata:

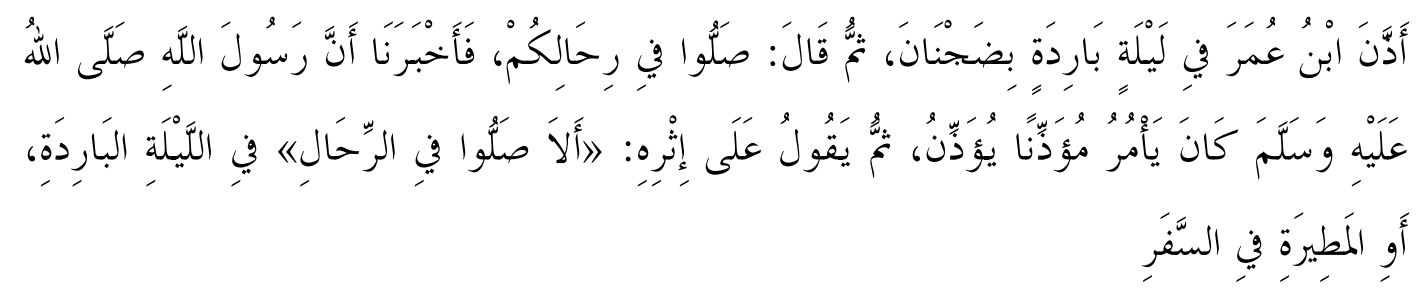

Artinya:

"Ibnu Umar radhiyallahu 'anhuma pernah azan di malam yang dingin di bukit Dhajnan. Kemudian beliau mengucapkan, "shallù fî rihālikum" (Salatlah di rihal kalian)!" Lalu beliau mengabarkan kepada kami bahwa Rasulullah shallallahu 'alaihi wasallam pernah memerintahkan seorang muazin untuk mengumandangkan azan, kemudian berseru setelah selesai azan, "Hendaklah kalian salat di rihal' pada malam yang dingin, atau saat turun hujan dalam perjalanan." 30

Makna rihal di riwayat tersebut adalah bentuk jamak dari rahl yang berarti rumah, tempat beristirahat atau tempat tinggal. ${ }^{31}$

Abdullah bin Abbas radhiyallahu 'anhuma mengatakan kepada muazinnya ketika turun hujan:

${ }^{29}$ Lihat: Mas'ud Shabri. Fatawa al-Ulama Haula Fairus Kuruna (Cet. I; Kairo: Daarul Basyir, 1441 H), h. 176. dan Kholid bin Ali Al-Musyaiqih, Al-Ahkam al-Fiqhiyyah al-Muta'alliqah bi Waba' Kuruna, h. 12. https://islamhouse.com/ar/books/2829154/

${ }^{30}$ H.R. Bukhari no. 632 dan Muslim no. 697.

${ }^{31}$ Mubarak bin Muhammad bin Muhammad Ibnu Al-Atsir, Al-Nihayah fi Gharib al-Hadits, Jilid II (Beirut: Al Maktabah Al Ilmiyyah, 1399 H), h. 209. 


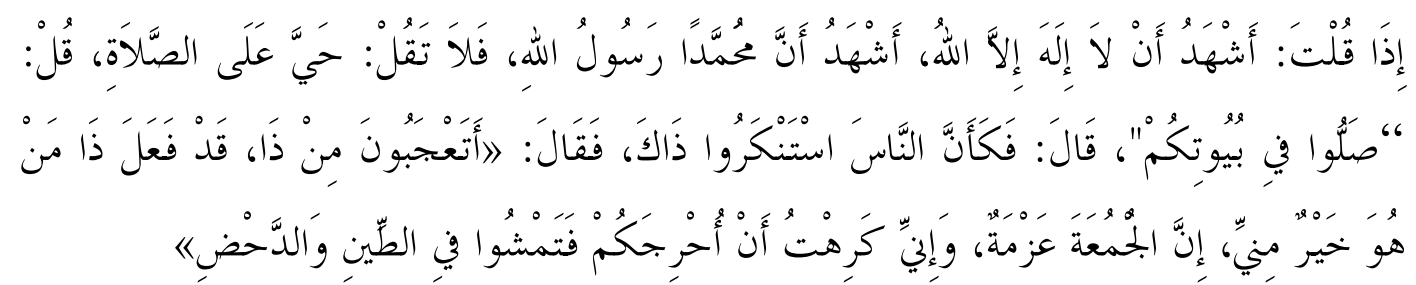

Artinya:

"Jika engkau telah mengucapkan "Asyhadu an lā ilāha illallāh, asyhadu anna Muhammadan Rasulullāh," maka janganlah kamu mengucapkan "Hayya alash shalāh," namun ucapkanlah "shallū fī buyütikum" (Salatlah kalian di rumah-rumah kalian)." Abdullah bin Abbas berkata, "Ternyata orang-orang sepertinya mengingkari dan merasa heran akan hal ini, lalu ia berkata, "Apakah kalian merasa heran terhadap ini semua?) Padahal yang demikian pernah dilakukan oleh orang yang lebih baik dariku. Salat Jumat memang wajib, namun aku tidak suka jika memberatkan kalian sehingga berjalan di lumpur dan becek"132

\section{Beberapa Lafaz yang Disyariatkan dalam Kondisi Adanya Uzur Berjemaah}

Berdasarkan beberapa riwayat hadis yang menyebutkan masalah ini dapat disimpulkan ada beberapa lafaz yang dicontohkan:

1) Shallū fì rihālikum ${ }^{33}$

2) Shallū fì buyūtikum ${ }^{34}$

3) Alā Shallū fir rihā̄ ${ }^{5}$

4) Ash Shalāh fir Rihāl ${ }^{36}$

Seluruh lafaz ini berdasarkan hadis-hadis yang sahih sehingga bisa diucapkan secara bergantian di waktu yang berbeda. Namun, sebagian ulama mengatakan jika berada di dalam kota maka muazin mengucapkan, "Shallu fī

${ }^{32}$ H.R. Bukhari no. 901 dan Muslim no. 699.

${ }^{33}$ Berdasarkan hadis yang diriwayatkan oleh Bukhari no. 632 dan Muslim no. 697 dari sahabat Abdullah bin Umar radhiyallahu 'anhuma.

${ }^{34}$ Berdasarkan hadis yang diriwayatkan oleh Bukhari no. 901 dan Muslim no. 699 dari sahabat Abdullah bin Abbas radhiyallahu 'anhuma.

35 Berdasarkan hadis yang diriwayatkan oleh Bukhari no. 632 dan Muslim no. 697 dari sahabat Abdullah bin Umar radhiyallahu 'anhuma, lihat footnote no. 95.

36 Berdasarkan hadis yang diriwayatkan oleh Bukhari no. 616 dari Abdullah bin Abbas radhiyallahu 'anhuma. 
buyütikum" dan jika berada di luar kota (dalam keadaan safar) maka dikumandangkan, "Shallü fì rihālikum." 37

\section{Hukum Mengucapkannya di Saat Terjadi Uzur Berjemaah ${ }^{38}$}

Para ulama berbeda pandangan dalam masalah ini dengan dua pendapat yang dikenal:

Pertama: Sunah, ini adalah pendapat mayoritas ulama kita. Ucapan muazin "shallū fì buyütikum" hukumnya mustahab dan tidak wajib sebagaimana yang dipahami dari perkataan Ibnu Rajab. ${ }^{39}$ Dengannya jika muazin tidak membacanya maka tidak berdosa.

Kedua: Wajib, ini pendapat yang dipilih oleh Ibnu Hazm Azh Zhohiri. ${ }^{40}$ Pendapat yang kuat dalam hal ini adalah apa yang disebutkan oleh jumhur ulama karena tidak ada dalil yang tegas akan kewajibannya. Lafaz ini diucapkan sebagai rukhsah dan keringanan bagi umat, wallahu a'lam. ${ }^{41}$

\section{Kondisi Apa yang Membolehkan Membacanya?}

Tidak ada perbedaan pendapat di kalangan ulama bahwa disyariatkan bagi muazin mengatakan "ash-shalätu fir rihäl" atau "shallū fî rihālikum" atau "shallu fi buyütikum" jika ada uzur menghadiri salat berjemaah berupa hujan lebat, lumpur, cuaca yang sangat dingin atau angin kencang. ${ }^{42}$ Faktor lain yang membenarkan ucapan tersebut adalah kejadian atau peristiwa besar yang menakutkan dan berbahaya seperti wabah menular atau selainnya yang mudah untuk menular seperti virus covid-19.43

\section{Kapan Lafaz Ini Diucapkan dalam Azan ${ }^{44}$}

${ }^{37}$ Lihat: Kholid bin Ali Al-Musyaiqih, Al-Ahkam al-Fiqhiyyah al-Muta'alliqah bi Waba' Kuruna, h. 12. https://islamhouse.com/ar/books/2829154/

${ }^{38}$ Lihat: Fahd bin Yahya Al 'Ammari, Ahkam Qaul al-Muadzdzin "Alaa Shalluu fii Rihaalikum", 1440 H. https://almoslim.net/elmy/290382

${ }^{39}$ Lihat: Abdurrahman bin Ahmad bin Rajab Al Hambali, Fath al-Bari Syarhu Shahih Al Bukhari, Jilid V (Cet, I; Madinah Nabawiyyah: Maktabah Al Ghuraba Al Atsariyyah, 1417 H), h.304.

${ }^{40}$ Ali bin Muhammad bin Said Ibnu Hazm, Al-Muhalla bil Atsar, Jilid II (Beirut: Daar Al Fikr), h.195.

${ }^{41}$ Lihat: Kholid bin Ali Al-Musyaiqih, Al-Ahkam al-Fiqhiyyah al-Muta'alliqah bi Waba' Kuruna, h. 12. https://islamhouse.com/ar/books/2829154/

${ }^{42}$ Lihat: Wizarah Al Awqaf wa Asy Syuun Al Islamiyyah, Al-Mausu'ah al-Fiqhiyyah alKuwaitiyah, Jilid II (Cet. II; Kuwait: Daar As Salaasil, 1404 H), h. 363.

${ }^{43}$ Lihat: Mas'ud Shabri, Fatawa al-Ulama Haula Fairus Kuruna, (Cet. I; Kairo: Daarul Basyir, 1441 H), h. 177.

${ }^{44}$ Lihat: Abdul Aziz bin Marzuq Al-Tharifi, Masaail al-Muhimmah fi al-Adzan wa al-Iqamah, (Cet. III; Riyadh: Maktabah Daar Al Minhaj, 1435 H), h. 97 dan Fahd bin Yahya Al 'Ammari, Ahkam Qaul al-Muadzdzin “Alaa Shalluu fii Rihaalikum”, 1440 H. https://almoslim.net/elmy/290382 
Para ulama kita berbeda pendapat tentang letak penyebutan kalimat "shallū fì buyūtikum" atau "shallū fì rihālikum," yaitu sebagai berikut:

Pendapat pertama, lafaz ini disebutkan setelah azan. Pendapat ini dipilih oleh sebagian ulama mazhab Syafi'i dan juga pendapat mazhab Hambali. Dalil dari pendapat ini berdasarkan riwayat Nafi' dari Abdullah bin Umar radhiyallahu 'anhuma yang telah disebutkan sebelumnya. ${ }^{45}$ Riwayat Ibnu Umar radhiyallahu anhuma menunjukkan bahwa lafaz ini disebutkan setelah azan dikumandangkan. Imam Syafii mengatakan:

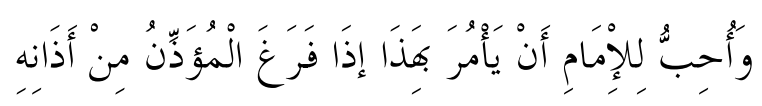

Artinya:

"Aku suka jika imam menyuruh muazin membaca ini (shallu fii rihaalikum) setelah mengumandangkan azan."46

Al-Hafizh Ibnu Hajar mengatakan, "Hadis (Ibnu Umar) sangat gamblang menyebutkan bahwa lafaz tersebut dikumandangkan setelah azan." ${ }^{47}$

Pendapat kedua, ucapan itu disebutkan di pertengahan azan sebagai pengganti ucapan "hayya 'alash shalah". Pendapat ini dipilih oleh mazhab Hanafi dan Hambali, juga pendapat sebagian dari ulama mazhab Syafi'i. Pendapat ini berdasarkan hadis dari Abdullah bin Abbas radhiyallahu 'anhuma yang juga telah disebutkan sebelumnya. ${ }^{48}$ Al-Hafizh Iraqi menjelaskan hal ini:

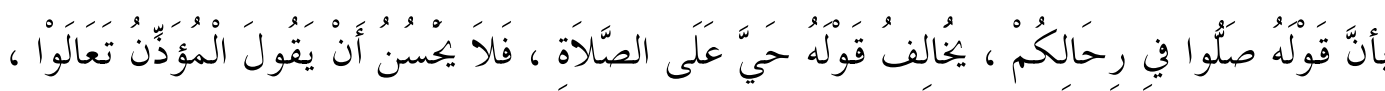

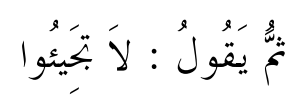

Artinya:

"Karena perkataan "Shallū fî rihālikum" bertentangan dengan makna panggilan "Hayya 'alā ash shalāh" maka tidak baik jika seorang muazin

${ }^{45}$ H.R. Bukhari no. 632 dan Muslim no. 697.

${ }^{46}$ Muhammad bin Idris bin Abbas Al-Syafi'i, Al-Umm, Jilid I (Beirut: Daarul Ma'rifah, 1410 H), h.109.

${ }^{47}$ Ahmad bin Ali bin Hajar Al 'Asqalani, Fath al-Bari Syarhu Shahih Al-Bukhari, Jilid II (Beirut: Daar Al-Ma'rifah, 1379 H), h. 113.

${ }^{48}$ H.R. Bukhari no. 901 dan Muslim no. 699. 
mengatakan "Kemari" kemudian dia katakan setelahnya "Jangan kalian datang." 49

Al-Hafizh Ibnu Hajar mengatakan:

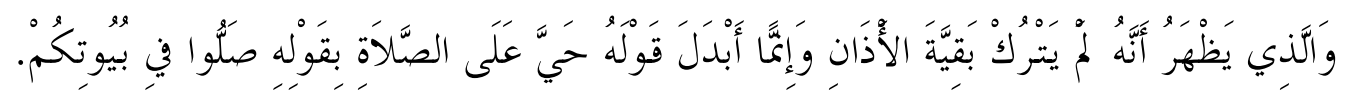
Artinya:

"Tampaknya beliau tidak meninggalkan bacaan azan yang lain, hanya saja beliau mengganti "hayya alā ash shalāh" dengan "Shallū fì buyütikum."

Ibnu Hajar juga menyebutkan alasan beberapa ulama yang memilih pendapat ini:

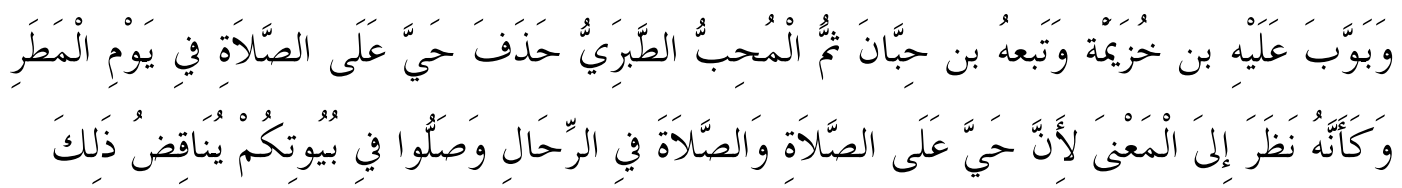

Artinya:

"Ibnu Khuzaimah menyebutkan judul bab terkait hal ini dan diikuti oleh Ibnu Hibban kemudian Muhibbuddin Ath Thabari bahwa ucapan itu dikumandangkan sebagai ganti "hayya "alā ash shalāh" pada saat hujan lebat. Tampaknya hal ini ditinjau dari sisi makna, karena "hayya 'alā ash shalāh" maknanya kemarilah kalian, sedangkan "Ash Shalāh fir rihäl' dan "shallū fì buyūtikum" bertentangan maknanya dengan itu (karena berarti tidak usah datang)." ${ }^{51}$

Kemudian Ibnu Hajar menanggapi pernyataan tersebut:

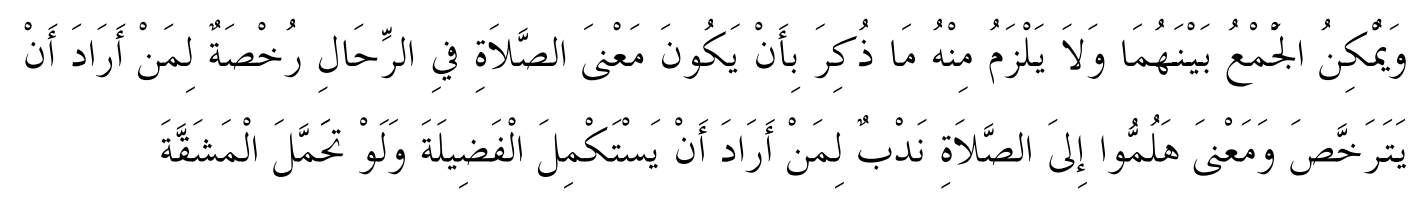
Artinya:

${ }^{49}$ Abdurrahim bin Husain bin Abdurrahman Al 'Iraqi, Tharhu al-Tatsrib fi Syarhi Al-Taqrib, Jilid II (Beirut: Daar Ihya' At Turots Al Arabi), h. 320.

${ }^{50}$ Ahmad bin Ali bin Hajar Al 'Asqalani, Fath al-Bari Syarhu Shahih Al-Bukhari, Jilid II (Beirut: Daar Al-Ma'rifah, 1379 H), h. 384.

${ }^{51}$ Ahmad bin Ali bin Hajar Al 'Asqalani, Fath al-Bari Syarhu Shahih Al-Bukhari, Jilid II (Beirut: Daar Al-Ma'rifah, 1379 H), h. 98. 
"Kedua lafaz ini bisa digabungkan (maknanya) dan tidak harus dipahami seperti yang dikatakan oleh Ibnu Khuzaimah, yaitu makna "Ash shalāh fir rihäl' adalah rukhsah bagi yang mau mengambil keringanan adapun "Hayya 'alā Ash Shalāh" yang berarti "Kemarilah mengerjakan salat" anjuran bagi yang ingin menyempurnakan keutamaan walaupun harus menanggung kesulitan." 52

Pendapat ketiga, boleh kedua-duanya dan ini pendapat sebagian ulama mazhab Hanafi dan mazhab Syafi'i. Hujah dari pendapat ini karena sunah telah menyebutkan kedua-duanya dengannya memberikan pilihan kepada muazin mengucapkan lafaz tersebut setelah azan atau menggantikan lafaz "Hayya 'ala ash shalāh'. Imam Syafi'i setelah memilih pendapat pertama, beliau menyatakan selanjutnya:

$$
\text { وَِإِنْ قَالَهُ فِي أَذَانَهِ فَلَا بَأْس عَلَلْهِ }
$$

Artinya:

"Namun, jika dia mengucapkannya pada pertengahan azannya maka tidak mengapa." 53

Imam Nawawi menjelaskan:

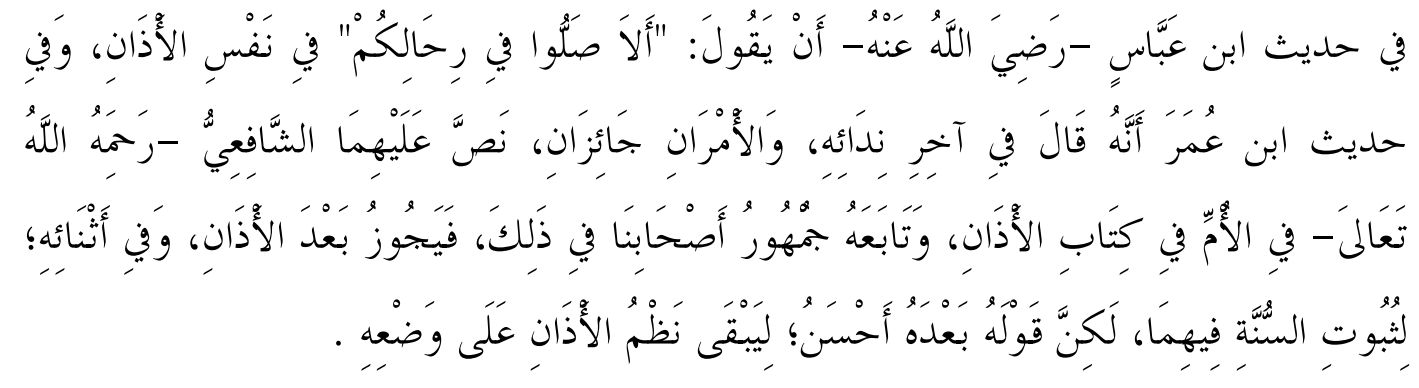

Artinya:

"Pada hadis Ibnu Abbas radhiyallahu 'anhuma disebutkan bahwa ucapan "Salatlah di tempat kalian" dimasukkan ke dalam bagian azan, adapun hadis Ibnu Umar diucapkan setelah setelah berazan. Keduanya dibolehkan sebagaimana yang ditegaskan oleh Syafii rahimahullah dalam kitab beliau Al Umm dalam pembahasan kitab Azan. Pendapat itu diikuti oleh mayoritas mazhab kami sehingga boleh diucapkan setelah azan dan di pertengahannya, karena keduanya memiliki dalil yang sahih. Akan tetapi

${ }^{52}$ Ahmad bin Ali bin Hajar Al 'Asqalani, Fath al-Bari Syarhu Shahih Al-Bukhari, Jilid II (Beirut: Daar Al-Ma'rifah, 1379 H), h. 113.

${ }^{53}$ Muhammad bin Idris bin Abbas Al-Syafi'i, Al-Umm, Jilid I (Beirut: Daarul Ma'rifah, 1410 H), h. 109. 
diucapkan setelah azan lebih baik agar lafaz-lafaz azan yang asal tetap dipertahankan pada tempatnya" 54

Ibnu Muflih setelah menyebutkan hadis Ibnu Abbas dan hadis Ibnu Umar radhiyallahu anhum, beliau berkata:

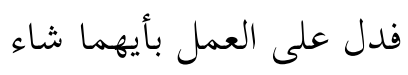

Artinya:

"Hal ini menunjukkan bahwa bolehnya mengamalkan di waktu apa saja yang diinginkannya." 55

Ibnu Rajab al-Hambali mengatakan:

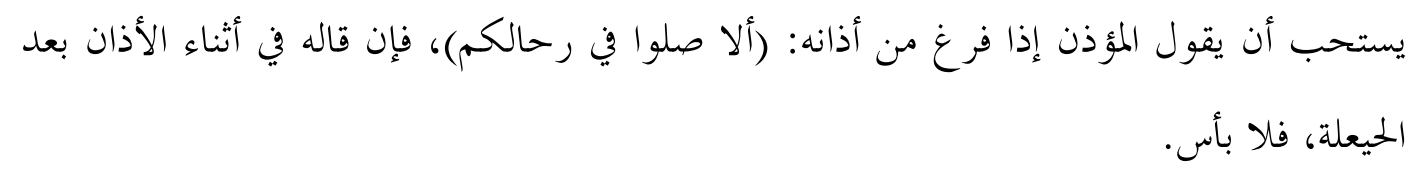

Artinya:

"Dianjurkan kepada muazin jika selesai dari azannya untuk mengucapkan 'alà shallū fî rihālikum", jika dia mengatakan di antara azannya setelah ucapan "hayya 'alā ash shalāh" maka tidak mengapa."56

Pendapat keempat, setelah mengucapkan "Hayya 'alā ash shalāh" dan "hayya 'alā al falāh". Pendapat ini adalah pendapat dari sebagian ulama mazhab Syafi'i dan juga pendapat Ibnu Hazm. ${ }^{57}$ Pendapat ini berdasarkan riwayat berikut:

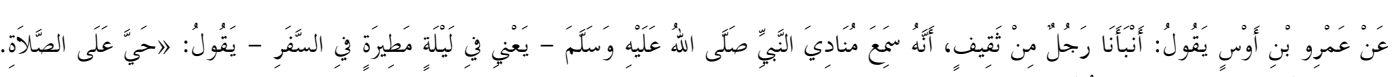

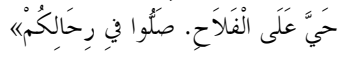

Artinya:

"Dari Amr bin Aus dia berkata; telah memberitakan kepada kami seorang laki-laki dari Tsaqif bahwasanya dia mendengar muazin Rasulullah shallallahu 'alaihi wasallam -pada malam turun hujan dalam suatu perjalanan- berkata, "Hayya 'alā ash shalāh" (Mari menuju salat), "Hayya

54 Yahya bin Syaraf Al-Nawawi, Al-Minhaj Syarhu Shahih Muslim bin Hajjaj, Jilid V (Cet. II; Beirut: Daar Ihya At Turots Al Arabi, 1392 H), h. 207.

${ }^{55}$ Muhammad bin Muflih bin Muhammad Al Hambali, Kitab Al-Furu', Jilid III (Cet. I; Beirut: Muassah Ar Risalah, 1424 H), h. 63.

${ }^{56}$ Lihat: Abdurrahman bin Ahmad bin Rajab Al Hambali, Fath al-Bari Syarhu Shahih Al Bukhari, Jilid V (Cet, I; Madinah Nabawiyyah: Maktabah Al Ghuraba Al Atsariyyah, 1417 H), h.304.

${ }^{57}$ Lihat: Ahmad bin Ali bin Hajar Al 'Asqalani, Fath al-Bari Syarhu Shahih Al-Bukhari, Jilid II (Beirut: Daar Al-Ma'rifah, 1379 H), h. 98 dan Ali bin Muhammad bin Said Ibnu Hazm, Al-Muhalla bil Atsar, Jilid II (Beirut: Daar Al Fikr), h. 195. 
'alā al falāh" (Mari menggapai kemenangan), "Shallū fì rihālikum" (Salatlah kalian di tempat-tempat kalian)." ${ }^{58}$

Kesimpulan dari keempat pendapat ini bahwa semuanya berdalilkan hadis-hadis yang sahih. Oleh karena itu, kita katakan ucapan "shallu fi rihālikum" dan semacamnya boleh diucapkan pada tiga tempat:

1) Setelah mengucapkan semua lafaz azan sebagaimana biasanya.

2) Lafaz ini letaknya sebagai pengganti "hayya 'alā ash shalāh" dan lafaz azan lainnya diucapkan sebagaimana biasanya.

3) Lafaz ini boleh juga diucapkan setelah mengucapkan "hayya 'alā ash shalāh" dan "hayya 'alā al falāh" sebelum ucapan "Allāhu akbar".

Dari ketiga pendapat tersebut tampaknya pendapat kedua yang paling gamblang dan juga lebih sesuai dengan maksud dan tujuan panggilan tersebut, wallahu a'lam.

\section{Berapa Kali Lafaz Ini Dikumandangkan?}

Ulama berbeda pendapat tentang jumlah ucapan lafaz ini dibaca pada saat azan, ada dua pendapat dalam hal ini.

Pendapat pertama, tidak ada jumlah yang pasti. Karena itu boleh diucapkan sekali atau sejumlah yang dipandang perlu oleh muazin. Hujah dari pendapat ini karena tidak ada dalil yang sahih menyebutkan jumlahnya. ${ }^{59}$

Pendapat kedua, muazin mengucapkannya dua kali, hal ini berdasarkan salah satu riwayat Ibnu Umar radhiyallahu anhuma. ${ }^{60}$ Pendapat kedua ini juga dikuatkan dengan dalil umum tentang lafaz azan, dimana Rasulullah shallallahu alaihi wasallam memerintahkan untuk melafazkannya dalam jumlah genap, wallahu a'lam. ${ }^{61}$

\section{Ucapan “Hayya 'alā al Falāh"}

${ }^{58}$ H.R. Nasai no. 653 dan Ahmad no. 23167, hadis ini dinilai sahih oleh al-Albani dalam Ats Tsamar Al Mustathab fi Fiqh As Sunnah wa Al Kitab (Cet. I; Kuwait: Muassasah Ghiras, 1422 H), h. 135 dan al-Arnauth di tahqiq beliau terhadap Musnad Ahmad, lihat: Ahmad bin Muhammad bin Hambal AlSyaibani, Musnad Imam Ahmad, Jilid XXXVIII, (Cet. I; Beirut: Muassasah Ar Risalah, 1421 H), h. 234.

${ }^{59}$ Abdul Aziz bin Marzuq al-Tharifi, Al-Masaail al-Muhimmah fi al-Adzan wa al-Iqamah, (Cet. III; Riyadh: Maktabah Daar Al Minhaj) h. 98.

${ }^{60}$ H.R. Imam Baihaqi dalam al-Sunan al-Kubra no. 5018, lihat: Kholid bin Ali Al-Musyaiqih, AlAhkam al-Fiqhiyyah al-Muta'alliqah bi Waba' Kuruna, h. 12. https://islamhouse.com/ar/books/2829154/

${ }^{61}$ H.R. Bukhari no. 603 dan Muslim no. 378 dari sahabat Anas bin Malik radhiyallahu 'anhu. 
Masalah berikutnya, berdasarkan pendapat kedua apakah muazin setelah mengucapkan "Shallū fì rihālikum" tetap mengucapkan "hayya 'alā al falāh" atau ucapan itu sebagai pengganti "hayya 'alā ash shalāh" dan "hayya 'alà al falah" sekaligus?. Syekh Ibnu Utsaimin pernah mengangkat masalah ini lalu beliau menjawab:

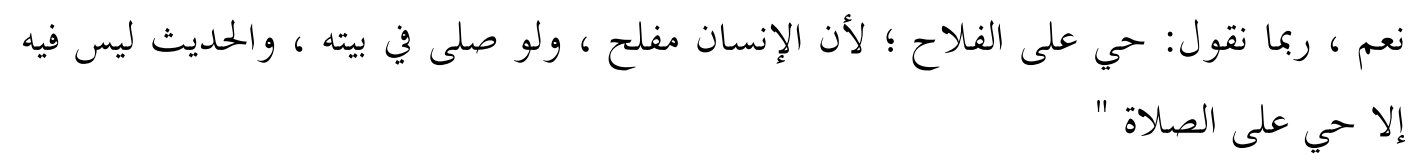

Artinya:

"Iya, mungkin kita tetap mengucapkan: "hayya alā al falāh" karena seseorang beruntung walaupun dia salat di rumahnya. Dalam hadis (Ibnu Abbas) tidak disebutkan dihilangkan (lafaz azan yang lain) kecuali "hayya alā ash shalāh". ${ }^{62}$

\section{Jawaban dari Ucapan Muazin}

Tidak terdapat dalil khusus yang menyebutkan apa bacaan yang diucapkan jika mendengarkan muazin membaca, "shallū fí rihālikum". Atas dasar itulah terdapat juga perbedaan pendapat di kalangan ulama tentang masalah ini:

Pendapat pertama, menjawab dengan ucapan "Là haula walā quwwata illā billāh". Hujahnya ucapan ini bagaikan ucapan "hayya alā ash shalāh" karena keduanya adalah ajakan dengannya kita bermohon pertolongan Allah. Permintaan tolong kepada Allah bukan hanya ketika menuju ke masjid akan tetapi secara umum ketika kita bangkit untuk melakukan ibadah yang dicintai dan diridainya. Hal ini disebutkan oleh sebagian ulama mazhab Syafi'i.

Pendapat kedua, tidak menjawab apa-apa. Ini pendapat sebagian ulama belakangan. Hujahnya karena ucapan ini kedudukannya seperti tatswib yang tidak ada dalil tegas tentang jawabannya. Pendapat ini juga merupakan konsekuensi dari pandangan mazhab Maliki.

Pendapat ketiga, menjawab sebagaimana yang dikatakan oleh muazin termasuk pada saat menjawab ucapan tatswib. Pendapat ini pendapat mayoritas fukaha. Hujah mereka berdasarkan keumuman sabda Nabi Muhammad shallallahu alaihi wasallam (artinya), "Katakanlah sebagaimana yang diucapkan oleh muazin."

${ }^{62}$ Muhammad bin Saleh bin Muhammad Al-Utsaimin, Ta’liqaat Ibn Utsaimin 'ala al-Kaafi, Jilid II, (Al Maktabah Asy Syamilah edisi 3,65), h. 36. 
Dari ketiga pendapat ini maka yang lebih tepat dengan kias adalah pendapat pertama dan ketiga. Hujahnya karena Nabi Muhammad shallallahu alaihi wasallam telah memerintahkan untuk mengucapkan "shalliū fí rihālikum" maka dengannya lafaz ini memiliki hukum lafaz-lafaz azan yang berdasarkan dalil syariat sehingga masuk dalam keumuman dalil untuk menjawabnya, baik itu diucapkan di pertengahan azan atau setelahnya, wallahu a'lam.

\section{KESIMPULAN}

Inilah beberapa hukum yang dapat penulis kumpulkan terkait dengan hukum azan khususnya di masa wabah covid-19 seperti sekarang ini. Di antara kesimpulan terpenting terkait masalah ini yaitu:

1) Dalam kondisi kaum muslimin tidak melaksanakan salat berjemaah di masjid maka tetap disyariatkan mengumandangkan azan di sebagian masjid kaum muslimin.

2) Ada perbedaan lafaz azan pada saat kondisi normal dan ketika ada uzur untuk hadir berjemaah.

\section{DAFTAR PUSTAKA}

Al-Qur'an.

Al-'Aini, Mahmud bin Ahmad bin Musa Al Hanafi. (1420 H). Al-Binayah Syarhu al-Hidayah. Cetakan pertama, Beirut, Daar Al Kutub Al 'Ilmiyyah.

Al-Albani, Muhammad Nashiruddin. Shahih al-Jami' al-Shaghir. Beirut, Al Maktab Al Islami.

Al-Albani, Muhammad bin Nashiruddin. (1422 H). Ats Tsamar Al Mustathab fi Fiqh As Sunnah wa Al Kitab. Cetakan pertama, Kuwait, Muassasah Ghiras.

Al 'Ammari, Fahd bin Yahya. (1440). Ahkam Qaul al-Muadzdzin "Alaa Shalluu fii Rihaalikum”. https://almoslim.net/elmy/290382

Al-Baghawi, Husain bin Mas'ud. (1417 H). Ma'alim At Tanzil/ Tafsir Al Baghawi. Cetakan keempat, Riyadh, Daar Thayyibah.

Al-Baihaqi, Ahmad bin Husain bin Ali. (1424 H). al-Sunan al-Kubra. Cetakan ketiga, Beirut, Daar Al Kutub Al Ilmiyyah.

Al-Bukhari, Muhammad bin Ismail bin Ibrahim. (1422 H). Al Jami'Al Musnad Ash Shahih Al Mukhtashar. Cetakan pertama, Daar Thauq An Najah. 
Al-Duways, Ahmad bin Abdurrazzaq. Fatawa al-Lajnah al-Daimah. Riyadh, Riasah Al Idarah Al Buhuts Al Ilmiyyah wa Al-Ifta.

Al-Hajj, al-Amin al-Hajj Muhammad Ahmad. (1426 H). Dalil al-Aimmah wa alMuadzdzinin. Cetakan pertama, Khartoum, Syarikah Mathabi’ As Sudan.

Al 'Iraqi, Abdurrahim bin Husain bin Abdurrahman. Tharhu al-Tatsrib fi Syarhi Al-Taqrib. Beirut, Daar Ihya' At Turots Al Arabi.

Al-Jurjani, Ali bin Muhammad bin Ali. (1403 H). Al-Ta'rifaat. Cetakan pertama, Beirut, Daar Al Kutub Al 'Ilmiyyah.

Al-Musyaiqih, Kholid bin Ali. Al-Ahkam al-Fiqhiyyah al-Muta'alliqah bi Waba' Kuruna. https://islamhouse.com/ar/books/2829154/

Al-Naisaburi, Muslim bin Hajjaj bin Muslim. Al Musnad Ash Shahih Al Mukhtashar. Beirut, Daar Ihya At Turots Al Arabi.

Al-Nasai, Ahmad bin Syuaib bin Ali. (1406 H). Sunan An Nasai. Cetakan kedua, Halab, Maktab Al Mathbu'at Al Islamiyah.

Al-Nawawi, Yahya bin Syaraf. Al-Majmu’ Syarhu Al Muhadzdzab. Beirut, Daar Al Fikr

Al-Nawawi, Yahya bin Syaraf. (1392 H). Al-Minhaj Syarhu Shahih Muslim bin Hajjaj. Cetakan kedua, Beirut, Daar Ihya At Turots Al Arabi.

Shabri, Mas'ud Shabri. (1441 H). Fatawa al-Ulama Haula Fairus Kuruna. Cetakan pertama, Kairo, Daarul Basyir.

Al-Sijistani, Abu Dawud Sulaiman bin Al Asy'ats. Sunan Abi Dawud. Beirut, Al Maktabah Al 'Ashriyah.

Al-Syaibani, Ahmad bin Muhammad bin Hambal. (1421 H). Musnad Imam Ahmad. Cetakan pertama, Beirut, Muassasah Ar Risalah.

Al-Syafi'i, Muhammad bin Idris bin Abbas. (1410 H). Al-Umm. Beirut, Daarul Ma'rifah.

Al-Tharifi, Abdul Aziz bin Marzuq. (1435 H). Masaail al-Muhimmah fi al-Adzan wa al-Iqamah. Cetakan ketiga, Riyadh, Maktabah Daar Al Minhaj.

Al-Tibrizi, Muhammad bin Abdullah Al Khatib Al 'Umari. (1985). Misykah alMashabih. Cetakan ketiga, Beirut, Al Maktab Al Islami.

Al-Tirmidzi, Muhammad bin Isa bin Saurah. (1395 H). Sunan At Tirmidzi, Cetakan kedua, Mesir, Maktabah Mushtafa Al Babi.

Al-Utsaimin, Muhammad bin Saleh bin Muhammad. Ta'liqaat Ibn Utsaimin 'ala al-Kaafi, Al Maktabah Asy Syamilah edisi 3,65.

Azwar Iskandar dan Khaerul Aqbar, Kedudukan Ilmu Ekonomi Islam di Antara Ilmu Ekonomi dan Fikih Muamalah: Analisis Problematika Epistemologis, Nukhbatul 'Ulum: Jurnal Bidang Kajian Islam, Vol. 5, No. 2 (2019), h. 88-105.

Ibnu Abdil Barr, Yusuf bin Abdullah bin Muhammad. (1421 H). Al-Istidzkar.

Cetakan pertama, Beirut, Daar Al Kutub Al Ilmiyyah. 
Ibnu Al-Atsir, Mubarak bin Muhammad bin Muhammad. (1399 H). Al-Nihayah fi Gharib al-Hadits. Beirut, Al Maktabah Al Ilmiyyah.

Ibnu Hazm, Ali bin Muhammad bin Said. Al-Muhalla bil Atsar. Beirut, Daar Al Fikr.

Ibnu Hubairah, Yahya bin bin Muhammad bin Hubairah. (1417 H). Al-Ifshah 'an Ma'aani Ash Shihah. Riyadh, Daar Al Wathan.

Ibnu Katsir, Ismail bin Umar bin Katsir. (1420 H). Tafsir Al Quran Al Azhim. Cetakan kedua, Riyadh, Daar Thayyibah.

Ibnu Muflih Al Hambali, Muhammad bin Muflih bin Muhammad. (1424 H). Kitab Al-Furu'. Cetakan pertama, Beirut, Muassah Ar Risalah.

Ibnul Mulaqqin, Umar bin Ali bin Ahmad. (1417 H). Al-I'lam bi Fawaid 'Umdah al-Ahkam. Cetakan pertama, Riyadh, Daar Al 'Ashimah.

Ibnu Qudamah, Abdullah bin Ahmad bin Muhammad Al Maqdisi. (1388 H). AlMughni, Maktabah Al Qahirah.

Ibnu Rajab Al Hambali, Abdurrahman bin Ahmad bin Rajab. (1417 H). Fath alBari Syarhu Shahih Al Bukhari. Cetakan pertama, Madinah Nabawiyyah, Maktabah Al Ghuraba Al Atsariyyah.

Ibnu Rusyd, Muhammad bin Ahmad bin Muhammad. (1425 H). Bidayah alMujtahid wa Nihyah al-Muqtashid. Kairo, Daar Al-Hadits.

Ibnu Taimiyah, Ahmad bin Abdul Halim bin Abdussalam. (1408 H). Al-Fatawa al-Kubra. Cetakan pertama, Beirut, Daar Al Kutub Al Ilmiyyah.

MUI. "Fatwa Penyelenggaraan Ibadah dalam Situasi Terjadi Wabah Covid-19." https://mui.or.id/berita/27674/fatwa-penyelenggaraan-ibadah-dalamsituasi-terjadi-wabah-covid-19/, (Diakses pada tanggal 22 April 2020).

Wizarah Al Awqaf wa Asy Syuun Al Islamiyyah, (1404 H). Al-Mausu'ah alFiqhiyyah al-Kuwaitiyah. Cetakan kedua, Kuwait, Daar As Salaasil. 